\title{
Pengaruh Penyakit Penyerta Kehamilan dan Kehamilan Ganda dengan Kejadian Bayi Berat Lahir Rendah di RSUD Arifin Achmad Provinsi Riau
}

\author{
Influence Accompany Disease of Pregnancy and Multiple Pregnancy to Low \\ Birth Weight in General Hospital Arifin Achmad Riau Province
}

\section{ANI TRIANA}

\author{
Program Studi D III Kebidanan Stikes Hang Tuah Pekanbaru
}

\begin{abstract}
ABSTRAK
Data yang diperoleh dari Rekam Medik RSUD Arifin Achmad Provinsi Riau dari tahun 2011 sampai 2013 untuk kejadian BBLR yaitu pada tahun 2011 tercatat 46 kasus (1,62\%) dari 2833 persalinan, tahun 2012 tercatat 179 kasus (5,44\%) dari 3290 persalinan dan tahun 2013 tercatat 130 kasus (4,56\%) dari 2848 persalinan dan BBLR masih termasuk ke dalam 3 besar dari 15 penyakit penyebab kematian Neonatal. Tujuan penelitian adalah diketahuinya faktor-faktor yang berhubungan dengan kejadian BBLR di RSUD Arifin Achmad Provinsi Riau Tahun 2011- 2013. Jenis penelitian yang digunakan adalah studi kasus kontrol (case control study). Kasus yaitu bayi lahir dengan BBLR di RSUD Arifin Achmad Riau tahun 2011-2013 berjumlah 355 orang dan kontrol yaitu bayi lahir dengan berat lahir normal di RSUD Arifin Achmad Riau tahun 2011-2013 berjumlah 355 orang. Hasil penelitian ibu dengan penyakit penyerta kehamilan lebih berisiko melahirkan dengan BBLR 10 kali (CI 95\% 6,2-16,6), ibu dengan kehamilan ganda lebih berisiko melahirkan dengan BBLR 15 kali (CI 95\% 4,8-45,1). Kesimpulan yaitu variabel independen yang memiliki hubungan sebab akibat dengan kejadian BBLR adalah umur, penyakit penyerta kehamilan, preeklampsia/eklampsia, kehamilan ganda, KPD, hidramnion dan plasenta previa. Saran ditujukan bagi tenaga kesehatan yaitu aktif dalam memberikan konseling, bagi RSUD Arifin Achmad Riau perlu keaktifan dalam upaya pencegahan BBLR.
\end{abstract}

Kata Kunci: Penyakit Penyerta Kehamilan, Kehamilan Ganda, Kejadian BBLR, RSUD Arifin Achmad Provinsi Riau

\begin{abstract}
Of data obtained from the Medical Records General Hospital Arifin Achmad Riau from 2011 to 2013 for that is LBW in 2011 registered 46 cases (1.62\%) of 2833 deliveries, 179 cases registered in 2012 (5.44\%) of the 3290 labor and in 2013 registered 130 cases (4.56\%) of 2848 births and LBW are still included in 3 of the 15 diseases causing neonatal mortality. Purpose of research is known factors related to LBW in General Hospital Arifin Achmad Riau Year 2011- 2013. Design of research is case-control study. The case is infat born to LBW in General Hospital Arifin Achmad Riau in 2011-2013 equal 355 respondent and control is infants born to normal birth weight in General Hospital Arifin Achmad Riau in 2011-2013 equal 355 respondent. The results of research maternal to Accompanying Disease Pregnancy is more risk of giving birth to LBW 10 times (95\% CI 6.2 -16.6) and maternal to more risk of having a multiple pregnancy to LBW 15 times (95\% CI 4,8-45.1). Conclusion that is the independent variables have causal relations with incidence of LBW is Age, Accompanying Disease Pregnancy, Preeclampsia/eclampsia, Multiple pregnancy, PROM, Hydramnion, Plasenta Previa. Advice is intended for health professionals that is active in counseling, the General Hospital Arifin Achmad Riau need liveliness LBW prevention.
\end{abstract}

Keyword: Accompanying Disease Pregnancy, LBW, General Hospital Arifin Achmad Riau Province

\section{PENDAHULUAN}

Bayi berat lahir rendah (BBLR) adalah bayi yang lahir dengan berat badan kurang atau sama dengan 2500 gram. Bayi Berat Lahir Rendah (BBLR) dan prematur merupakan penyebab kematian neonatal yang tinggi yaitu sebesar 30,3\%. Neonatal dengan BBLR beresiko mengalami kematian 6,5 kali lebih besar dari pada bayi yang lahir dengan berat badan normal. Disamping itu BBLR memiliki risiko kematian yang lebih tinggi dibandingkan dengan
BBLN ketika dilahirkan, khususnya kematian pada masa perinatal (SDKI, 2012).

Hasil data SDKI 2007 - 2012, menunjukkan bahwa AKB di Provinsi Riau cenderung menurun. Jumlah AKB di provinsi Riau dari tahun 2007, adalah 37 per 1000 kelahiran hidup menjadi 24 per 1000 kelahiran hidup pada tahun 2012. Penurunan angka kematian bayi ini menjadikan Provinsi Riau menduduki peringkat ketiga di Indonesia dengan angka kematian bayi terendah. Namun demikian, angka kematian bayi di Provinsi Riau yang disebabkan

Alamat Korespodensi : Ani Triana. Jl. Singgalang V “Perum Griya Idaman/Komplek Pemda” Blok A No. 4 RT. 04 RW. 05, Kel. Sail, Kec. Tenayan Raya, Hp: 08121096 0607, email: triana aniz@yahoo.com 
oleh BBLR masih tinggi yaitu sebesar $(29,79 \%)$, asfiksia $(31,46 \%)$, dan sebab lain $(36,93 \%)$ (Profil Kesehatan Provinsi Riau, 2012).

Berdasarkan studi pendahuluan di RSUD Arifin Achmad Provinsi Riau diperoleh data persalinan pada tahun 2011 bayi yang lahir dengan BBLR tercatat sebesar 46 kasus $(1,62 \%)$ dari 2833 persalinan, tahun 2012 tercatat sebesar 179 kasus $(5,44 \%)$ dari 3290 persalinan dan tahun 2013 tercatat sebesar 130 kasus (4,56\%) dari 2848 persalinan dan BBLR masih termasuk ke dalam 3 besar dari 15 penyakit penyebab kematian Neonatal. (RSUD Arifin Achmad Provinsi Riau, 2013).

Masih tingginya kasus BBLR di RSUD Arifin Achmad Provinsi Riau dapat dipengaruhi oleh beberapa faktor. Selain faktor maternal yang berhubungan secara signifikan terhadap kejadian BBLR, juga terdapat beberapa faktor lain yang diduga berhubungan dengan kejadian BBLR seperti faktor janin, faktor plasenta, dan faktor lingkungan. Tujuan Penelitian adalah diketahuinya faktor-faktor yang berhubungan dengan Kejadian BBLR di RSUD Arifin Achmad Province Riau tahun 2011-2013.

\section{METODE}

Jenis penelitian yang digunakan adalah studi kasus kontrol (case control study). Kasus yaitu bayi lahir dengan BBLR di RSUD Arifin Achmad Riau tahun 2011-2013 dan kontrol yaitu bayi lahir dengan berat lahir normal di RSUD Arifin Achmad Riau tahun 2011-2013. Dengan metode perhitungan ukuran sampel untuk Jenis kasus kontrol dengan: $\alpha 5 \%, \beta$ $10 \%, \mathrm{OR}=2$, didapatkan 355 kasus dan 355 kontrol.

Prosedur pengambilan sampel mulai dilakukan bulan Desember 2013, diurutkan ke belakang sampai Januari 2011. Kasus dan kontrol didapatkan dari catatan rekam medik RSUD Arifin Achmad Riau. Jenis data yang dikumpulkan adalah data sekunder yaitu kasus dan bukan kasus kejadian BBLR yang sama-sama diambil dari sumber data yaitu rekam medis di RSUD Arifin Achmad Riau tahun 2011-2013 dengan menggunakan daftar cheklist. Data sekunder tersebut terdiri dari 8 variabel yang diteliti yaitu variabel umur ibu, paritas, penyakit penyerta kehamilan, preeklampsia/eklampsia, kehamilan ganda, KPD, Hidramnion, dan Plasenta Previa.

Pengolahan data dilakukan dalam tahap-tahap editing, coding, processing, cleaning dan tabulating. Analisis data dilakukan yaitu analisis univariat, analisis bivariat dengan uji chi square dan analisis multivariat dengan multiple logistic regression.

\section{HASIL}

\section{Analisis Univariat}

Pada analisa univariat didapatkan hasil mayoritas ibu tidak berisiko yaitu pada variabel umur mayoritas ibu 20-35 tahun sebanyak 367 orang (51,7,2\%), mayoritas paritas ibu 1-4 yaitu sebanyak 415 orang $(58,5 \%)$, tidak ada penyakit penyerta kehamilan yaitu sebanyak 442 orang $(62,3 \%)$, kehamilan tunggal yaitu sebanyak 401 orang $(56,5 \%)$, Tidak dengan KPD sebanyak 506 orang $(71,3 \%)$, tidak hidramnion sebanyak 529 orang $(74,5 \%)$ serta tidak dengan plasenta previa yaitu sebanyak 620 orang $(87,3 \%)$.

Tabel 1

Analisis Univariat

\begin{tabular}{llc}
\hline \multicolumn{1}{c}{ Variabel } & N=710 & $\mathbf{\%}$ \\
\hline Umur Ibu & & \\
$<20$ dan $>35$ tahun & 343 & 48,3 \\
$20-35$ tahun & 367 & 51,7 \\
Paritas & & \\
0 dan $>4$ & 295 & 41,5 \\
$1-4$ & 415 & 58,5 \\
Penyakit penyerta kehamilan & & \\
Ada & 268 & 37,7 \\
Tidak Ada & 442 & 62,3 \\
Pre eklampsia/eklampsia & & \\
Ya & 222 & 31,3 \\
Tidak & 488 & 68,7 \\
Kehamilan Ganda & & \\
Kehamilan Ganda & 309 & 43,5 \\
Kehamilan Tunggal & 401 & 56,5 \\
KPD & & \\
Ya & 204 & 28,7 \\
Tidak & 506 & 71,3 \\
Hidramnion & & \\
Ya & \\
Tidak & 181 & 25,5 \\
Plasenta Previa & 529 & 74,5 \\
Ya & & \\
Tidak & 90 & 12,7 \\
\hline & 620 & 87,3 \\
\hline
\end{tabular}

\section{Analisis Bivariat}

Dari hasil analisis bivariat didapatkan seluruh variabel yang berjumlah 8 variabel berhubungan secara signifikan yaitu umur ibu ( $p$ value $=0,0001)$, paritas $(p$ value $=0,0001)$, penyakit penyerta kehamilan ( $p$ value $=0,0001)$, pre eklampsia/eklampsia $(p$ value $=$ $0,0001)$, kehamilan ganda ( $p$ value $=0,0001), \operatorname{KPD}(p$ value $=0,0001)$, hidramnion $(p$ value $=0,0001)$ dan plasenta previa $(p$ value $=0,0001)$. 
Tabel 2

Hasil Analisis Bivariat

\begin{tabular}{|c|c|c|c|c|c|c|c|c|}
\hline \multirow{3}{*}{ Variabel } & \multicolumn{6}{|c|}{ Kondisi Berat Badan Bayi } & \multirow{3}{*}{$\begin{array}{l}(P \\
\text { Value })\end{array}$} & \multirow{3}{*}{$\begin{array}{l}\text { OR/ } \\
\text { (CI 95\%) }\end{array}$} \\
\hline & \multicolumn{2}{|c|}{ Kasus } & \multicolumn{4}{|c|}{ Kontrol } & & \\
\hline & $\mathrm{n}$ & $\%$ & $\mathrm{n}$ & $\%$ & $\mathbf{N}$ & $\%$ & & \\
\hline \multicolumn{9}{|l|}{ Umur Ibu* } \\
\hline$<20$ dan $>35$ tahun & 223 & 62,8 & 120 & 33,8 & 343 & 48,3 & \multirow[t]{2}{*}{0,0001} & \multirow{2}{*}{$\begin{array}{l}3,308 \\
(2,432-4,500)\end{array}$} \\
\hline $20-35$ tahun & 132 & 37,2 & 235 & 66,2 & 367 & 51,7 & & \\
\hline \multicolumn{9}{|l|}{ Paritas* } \\
\hline 0 dan $>4$ & 213 & 60 & 82 & 23,1 & 295 & 41,5 & \multirow{2}{*}{0,0001} & \multirow{2}{*}{$\begin{array}{l}4,994 \\
(3,606-6,916)\end{array}$} \\
\hline $1-4$ & 142 & 40 & 273 & 76,9 & 415 & 58,5 & & \\
\hline \multicolumn{9}{|l|}{$\begin{array}{l}\text { Penyakit penyerta } \\
\text { kehamilan* }\end{array}$} \\
\hline Ada & 206 & 58 & 62 & 17,5 & 268 & 37,7 & \multirow[t]{2}{*}{0,0001} & \multirow{2}{*}{$\begin{array}{l}6,534 \\
(4,624-9,232)\end{array}$} \\
\hline Tidak Ada & 149 & 42 & 293 & 82,5 & 442 & 62,3 & & \\
\hline \multicolumn{9}{|c|}{$\begin{array}{l}\text { Pre } \\
\text { eklampsia/eklampsia* }\end{array}$} \\
\hline Ya & 164 & 46,2 & 58 & 16,3 & 222 & 31,3 & \multirow[t]{2}{*}{0,0001} & \multirow{2}{*}{$\begin{array}{l}4,397 \\
(3,097-6,241)\end{array}$} \\
\hline Tidak & 191 & 53,8 & 297 & 83,7 & 488 & 68,7 & & \\
\hline \multicolumn{9}{|l|}{ Kehamilan Ganda* } \\
\hline Kehamilan Ganda & 229 & 64,5 & 80 & 22,5 & 309 & 43,5 & \multirow[b]{2}{*}{0,0001} & \multirow[b]{2}{*}{$\begin{array}{l}6,248 \\
(4,489-8,695\end{array}$} \\
\hline Kehamilan Tunggal & 126 & 35,5 & 275 & 77,5 & 401 & 56,5 & & \\
\hline \multicolumn{9}{|l|}{ KPD* } \\
\hline Ya & 138 & 38,9 & 66 & 18,6 & 204 & 28,7 & \multirow[t]{2}{*}{0,0001} & \multirow{2}{*}{$\begin{array}{l}2,785 \\
(1,978-3,921\end{array}$} \\
\hline Tidak & 217 & 61,1 & 289 & 81,4 & 506 & 71,3 & & \\
\hline \multicolumn{9}{|l|}{ Hidramnion* } \\
\hline $\mathrm{Ya}$ & 127 & 35,8 & 54 & 15,2 & 181 & 25,5 & \multirow[t]{2}{*}{0,0001} & \multirow{2}{*}{$\begin{array}{l}3,105 \\
(2,162-4,459)\end{array}$} \\
\hline Tidak & 228 & 64,2 & 301 & 84,8 & 529 & 74,5 & & \\
\hline \multicolumn{9}{|l|}{ Plasenta Previa* } \\
\hline Ya & 68 & 19,2 & 22 & 6,2 & 90 & 12,7 & \multirow[t]{2}{*}{0,0001} & \multirow{2}{*}{$\begin{array}{l}3,586 \\
(2,162-5,948)\end{array}$} \\
\hline Tidak & 287 & 80,8 & 333 & 93,8 & 620 & 87,3 & & \\
\hline
\end{tabular}

*Variabel kandidat untuk analisis multivariat Signifikansi $(\alpha: 0,05)$

\section{Analisis Multivariat}

Tabel 3

Pemodelan Multivariat Akhir

\begin{tabular}{lllll}
\hline \multicolumn{1}{c}{ Variabel } & \multicolumn{1}{c}{ P } & OR & \multicolumn{2}{c}{$\begin{array}{c}\text { 95\% CI. For } \\
\text { EXP (B) }\end{array}$} \\
& & & Lower & Upper \\
\hline Umur Ibu & 0,0001 & 7,899 & 4,708 & 13,253 \\
$\begin{array}{l}\text { Paritas } \\
\text { Penyakit penyerta } \\
\text { kehamilan }\end{array}$ & 0,824 & 1,134 & 0,374 & 3,441 \\
Pre & & 10,122 & 6,182 & 16,573 \\
eklampsia/eklamp & 0,0001 & 7,731 & 4,664 & 12,815 \\
sia & & & & \\
Kehamilan ganda & 0,0001 & 14,804 & 4,856 & 45,131 \\
KPD & 0,0001 & 3,838 & 2,297 & 6,412 \\
Hidramnion & 0,0001 & 2,616 & 1,551 & 4,411 \\
Plasenta previa & 0,001 & 3,410 & 1,626 & 7,152 \\
\hline
\end{tabular}

Untuk analisis multivariat dilakukan beberapa tahapan yang pertama yaitu seleksi bivariat untuk mengetahui variabel mana yang akan dimasukan kedalam permodelan multivariat. Selanjutnya pemeriksaan counfounding (perubahan OR $>10 \%$ ) dengan mengeluarkan variabel yang $p$ valuenya $\geq 0,05$ secara bertahap dari $p$ value yang besar. Pada penelitian ini didapatkan hasil pada permodelan akhir variabel yang berhubungan signifikan terhadap kejadian BBLR berturut-turut yaitu umur, penyakit penyerta kehamilan, preeklampsia/eklampsia, kehamilan ganda, KPD, hidramnion dan plasenta previa.

\section{PEMBAHASAN}

\section{Umur Ibu}

Pada penelitian ini ditemukan bahwa umur ibu $<20$ dan $>35$ tahun berisiko 8 kali menyebabkan terjadinya BBLR dibandingkan ibu yang berusia 20-35 tahun (OR 7,899 CI 95\% (4,708-13,253)). Umur reproduksi sehat bagi seorang wanita untuk melahirkan anak adalah antara 20 sampai dengan 35 tahun (Jaya, 2009). Hal ini juga dinyatakan oleh (Dandehar, Shafee, Sinha, 2014) bahwa usia ibu yang muda mengakibatkan uterus tidak adekuat untuk berkembang dan dapat menyebabkan BBLR. Hal yang sama juga 
ditemukan pada penelitian Sutan, R, dkk, 2014 dengan OR 2,89 CI 95\% $(1,86-4,51) \mathrm{p}$ value $<0,001$ bahwa umur ibu ditemukan berhubungan signifikan dengan kejadian BBLR dan hal ini berhubungan dengan penurunan gizi pada umur yang masih remaja dan kelompok umur yang lebih tua disebabkan karena pola makan yang buruk. Peningkatan resiko penyakit kronis seperti Diabetus Militus dan penyakit jantung untuk umur ibu yang lanjut juga dapat menyebabkan bayi prematur dan pembatasan perkembangan janin atau pertumbuhan intrauterine karena kesehatan ibu yang buruk.

Berdasarkan hasil penelitian ini perlu direkomendasikan kepada ibu hamil mengingat bahwa faktor umur memegang peranan penting terhadap derajat kesehatan dan kesejahteraannya serta bayi, maka sebaiknya merencanakan kehamilan di usia reproduksi aman yaitu 20-35 tahun.

\section{Penyakit penyerta kehamilan}

Pada penelitian ini ditemukan bahwa ibu yang memiliki penyakit penyerta kehamilan berisiko 10 kali menyebabkan BBLR dibandingkan ibu yang tidak memiliki penyakit penyerta kehamilan (OR 10,122 CI 95\% (6,182-16,573)). Hasil penelitian ini sesuai dengan pendapat Suparyanto (2012), yang mengatakan bahwa ibu yang mengalami berbagai penyakit kehamilan seperti penyakit infeksi, non infeksi, hipertensi, dll akan membayakan kondisi ibu dan janin. Penyakit-penyakit tersebut dapat mengganggu proses fisiologis metabolisme dan pertukaran gas pada janin yang akan berakibat terjadinya kelahiran premature sehingga beresiko BBLR. Penelitian ini didukung oleh hasil penelitian Sistiarani (2008), dengan hasil nilai $p$ value $=0,03$ dan $\mathrm{OR}=2,91(95 \% \mathrm{CI}: 1,1-8,2)$ artinya ibu yang mengalami penyakit selama kehamilan mempunyai peluang melahirkan BBLR 3 kali dibandingkan ibu yang tidak mengalami penyakit selama kehamilan.

Berdasarkan hasil penelitian maka perlu direkomendasikan kepada ibu hamil yang memiliki penyakit penyerta kehamilan baik yang telah dilami setelah atau sebelum hamil untuk melakukan pemantauan melalui pemeriksaan ANC secara teratur selama masa kehamilan minimal 4 kali. Hal ini dilakukan agar kesehatan ibu dan janin dapat terpantau dengan baik dan dapat mencegah terjadinya BBLR. Bagi tenaga kesehatan untuk melakukan kunjungan rumah bagi ibu hamil yang tidak terpantau atau yang tidak melakukan kunjungan ANC rutin ke fasilitas kesehatan sehingga sejak dini terdeteksi kegawatdaruratan yang diakibatkan penyakit penyerta pada kehamilan.

\section{Pre Eklampsia/Eklampsia}

Pada penelitian ini ditemukan bahwa ibu yang memiliki pre eklampsia/eklampsia berisiko 8 kali menyebabkan BBLR dibandingkan ibu yang tidak memiliki pre eklampsia/eklampsia (OR 7,731 CI 95\% $(4,664-12,815))$. Hal ini sesuai dengan teori yang dikemukakan oleh Prawirohardjo (2007), bahwa ibu dengan preeklamsi mengalami perubahan fisiologi patologi diantarnya perubahan pada plasenta dan uterus yaitu menurunnya aliran darah ke plasenta yang mengakibatkan gangguan fungsi plasenta, yang jika berlangsung lama pertumbuhan janin akan terganggu. Sedangkan tonus uterus dan kepekaan terhadap rangsangan pada preeklamsi dan eklamsi mudah terjadi partus prematurus yang mengakibatkan bayi lahir dengan berat badan rendah. Hasil penelitian ini sejalan dengan penelitian Asih (2006), bahwa Hasil uji Chi Square didapatkan nilai $p$ value $<0,05$ sehingga dapat disimpulkan bahwa ada hubungan antara preeklamsi dengan kejadian BBLR.

Berdasarkan hasil penelitian ini perlu direkomendasikan kepada ibu hamil agar diupayakan melakukan deteksi dini dalam hal pencegahan terjadinya preeklampsia/eklampsia dapat melalui kunjungan ANC rutin serta disarankan kepada tenaga kesehatan dapat memberikan informasi melalui konseling kepada ibu dan keluarga tentang bahaya terjadinya preeklampsia/ekampsia.

\section{Kehamilan Ganda}

Pada penelitian ini ditemukan bahwa ibu dengan kehamilan ganda berisiko 15 kali menyebabkan BBLR dibandingkan ibu dengan kehamilan tunggal (OR 14,804 CI 95\% (4,856$45,131)$ ). Hal ini sesuai dengan pendapat Fadlun (2012), bahwa pertumbuhan janin pada kehamilan kembar rentan mengalami hambatan, karena penegangan uterus yang berlebihan oleh karena besarnya janin, 2 plasenta dan air ketuban yang lebih banyak menyebabkan terjadinya partus prematurus. Berat badan janin kembar berselisih antara 50-100 gram. Berat badan 1 janin pada pada kelahiran kembar rata-rata lebih ringan dari pada janin tunggal yaitu kurang dari 2500 gram. Penelitian ini diperkuat oleh hasil penelitian Merzalia (2012), dengan hasil uji ststistik diperoleh nilap $p$ value $=0,002$ maka dapat disimpulkan ada hubungan bermakna antara kehamilan ganda dengan bayi berat lahir rendah. Penelitian Altuncu (2006) juga menunjukkan hasil yang sama dengan hasil penelitian sekarang, yaitu ada hubungan yang signifikan antara kehamilan ganda dengan kejadian BBLR dengan nilai $p$ value $=0,0001$ dimana ibu dengan kehamilan ganda memiliki resiko melahirkan BBLR 5 kali dibandingkan ibu yang tidak hamil ganda.

Pada penelitian ini kehamilan ganda mengalami confounding dengan paritas, hal ini disebabkan karena bayi kembar merancukan jumlah paritas. Perlu diketahui bahwa kehamilan ganda bisa melebihi 2 orang janin yang dikandung sehingga 
jumlah paritas akan mengalami perbedaan dengan ibu yang hamil tunggal yang hanya 1 kali melahirkan dengan jumlah paritas hanya 1 .

Berdasarkan hasil penelitian ini perlu disarankan kepada tenaga kesehatan untuk segera melakukan rujukan atau kalaborasi dengan dokter spesialis kebidanan dan kandungan, karena kehamilan ganda termasuk kedalam kehamilan berisiko dan perlu pemantauan yang ketat terutama berat badan bayi.

\section{Ketuban Pecah Dini (KPD)}

Pada penelitian ini ditemukan bahwa ibu dengan KPD berisiko 4 kali menyebabkan BBLR dibandingkan ibu yang tidak KPD (OR 3,838 CI 95\% $(2,297-6,412))$. Hal ini sesuai dengan pendapat Fadlun (2012), bahwa KPD pada usia kehamilan kurang dari 37 minggu atau disebut juga Preterm Premature Rupture Of Membrane sehingga dapat mengakibatkan bayi lahir dengan berat badan rendah (BBLR). Hasil penelitian ini diperkuat oleh penelitian yang dilakukan oleh Nugroho (2012) yang didapatkan hasil analisis karakteristik berat lahir bayi dengan nilai $p$ value $=0,0001$.

Ibu dengan KPD perlu penanganan yang cepat dikarenakan jika terjadi persalinan prematur akibat KPD yang berisiko terjadinya infeksi sedangkan bayi mengalami BBLR akan mempermudah terjadinya peningkatan morbiditas dan mortalitas pada bayi baru lahir sehingga ibu yang mengalami KPD dapat diupayakan mempertahankan kehamilan sampai mencapai usia kehamilan aterm sehingga diharapkan bayi lahir dengan berat badan normal.

\section{Hidramnion}

Pada penelitian ini ditemukan bahwa ibu dengan hidramnion berisiko 3 kali menyebabkan BBLR dibandingkan ibu yang tidak hidramnion (OR 2,616 CI 95\% (1,551-4,411)). Menurut Prawirohardjo (2007) bahwa hidramnion merupakan kehamilan dengan jumlah air ketuban $>2$ liter. Hal ini terjadi bila produksi air ketuban bertambah serta dikarenakan terganggunya pengaliran air ketuban. Akibat dari masalah tersebut, maka akan terjadi keracunan kehamilan, premature dan BBLR serta pendarahan.

Berdasarkan penelitian ini perlu direkomendasikan bagi ibu hamil untuk tetap selalu melkukan kunjungan pemeriksaan ANC dan mendapatkan konseling pra kehamilan, masa kehamilan maupun pasca melahirkan secara tertur dan intensif oleh karena itu diharapkan tenaga kesehatan terutama bidan memberikan informasi sejelas-jelasnya dan melakukan deteksi dini serta pemantauan kehamilan dengan tepat dan cepat sehingga dapat mencegah terjadinya hidramnion dikarenakan hidramnion dapat menyebabkan terjadinya BBLR.

\section{Plasenta previa}

Pada penelitian ini ditemukan bahwa ibu dengan plasenta previa berisiko 3 kali menyebabkan BBLR dibandingkan ibu yang tidak dengan plasenta previa (OR 3,410 CI 95\% (1,626-7,152)). Hal ini sesuai dengan pendapat Fadlun (2012), keadaan plasenta yang tidak normal dapat menimbulkan berbagai komplikasi baik pada ibu maupun janin, komplikasi tersebut dianataranya adalah prematuritas dengan berat badan bayi lahir rendah yaitu kurang dari 2500 gram.

Tetap perlu pengawasan kehamilan pada ibu hamil, sehingga dengan adanya pengawasan tenga kesehatan dapat mendeteksi dini komplikasi kehamilan. Hal ini juga perlu kerjasama dengan tenaga kesehatan yang lain salah satunya dokter.

\section{KESIMPULAN}

Variabel independen yang memiliki hubungan sebab akibat dengan kejadian BBLR adalah umur, penyakit penyerta kehamilan, preeklampsia/eklampsia, kehamilan ganda, KPD, hidramnion dan plasenta previa. Adapun Hasil penelitian ibu yang umurnya $<20$ dan $>35$ tahun lebih berisiko melahirkan dengan BBLR 8 kali (CI 95\% 4,7-13,2), ibu dengan penyakit penyerta kehamilan lebih berisiko melahirkan dengan BBLR 10 kali (CI 95\% 6,2-16,6), ibu dengan preeklampsia/eklampsia lebih berisiko melahirkan dengan BBLR 8 kali (CI 95\% 4,7-12,8), ibu dengan kehamilan ganda lebih berisiko melahirkan dengan BBLR 15 kali (CI 95\% 4,8-45,1), ibu dengan KPD lebih berisiko melahirkan dengan BBLR 4 kali (CI 95\% 2,3-6,4), ibu dengan hidramnion lebih berisiko melahirkan dengan BBLR 3 kali (CI 95\% 1,5-4,4), ibu dengan plasenta previa lebih berisiko melahirkan dengan BBLR 3 kali (CI 95\% 1,6-7,1).

\section{SARAN}

Kepada ibu hamil yang mengalami risiko terjadinya BBLR untuk dapat melakukan pemeriksaan kehamilan (ANC) secara teratur minimal 4 kali selama kehamilan dan perlunya ibu hamil mendapatkan informasi melalui konseling tentang BBLR dan faktorfaktor yang berisiko. Diharapkan tenaga kesehatan juga mampu mendetksi dini segala komplikasi dan tidak terlambat dalam melakukan rujukan dan dapat berkalaborasi dengan dokter spesialis kebidanan dan kandungan dalam upaya pencegahan BBLR.

\section{UCAPAN TERIMA KASIH}

Ucapan terima kasih ditujukan kepada Elsi Fitriani yang telah membantu dalam proses pengumpulan data penelitian, Direktur RSUD Arifin Achmad Provinsi Riau yang telah memberikan izin penelitian, dan seluruh Staff kebidanan yang telah membantu secara moril. 


\section{DAFTAR PUSTAKA}

Altuncu, E. et all. (2006). The Incidence Of Low Birth Weight In 5000 Liveborn Infants And The Etiology Of Fetal Risk Factors. Marmara medical journal 2006;19(2);46-51.

Asih, Y. dkk. (2006). Hubungan Antara Preeklamsi Pada Primigravida dengan Berat Badan Lahir Rendah di RSUD Cilacap Periode JanuariDesember 2005. Jurnal Keperawatan Soedirman (The Soedirman Journal of Nursing), Volume 1, No. 2.

Dandehar, R.H. (2014). Prevalance and Risk Factors Affecting Low Birth Weight in a District Hospital at Perambalur, Tanilnadu. Global Journal of Medicine and Public Health. Vol. 3 Issue. 2, ISSN: 2277-9604

Fadlun. dkk. (2012). Asuhan Kebidanan Patologis. Jakarta: Salemba Medika.

Jaya, N. (2009). Analisis Faktor Risiko Kejadian Bayi Berat Lahir Rendah di Rumah Sakit Ibu dan Anak Siti Fatimah Kota Makasar. Jurnal Media Gizi Pangan. Vol. VII Edisi 1, JanuariJuni, Jurusan Keperawatan, Politeknik Kesehatan Makasar.

Merzalia, N. (2012). Determinan Kejadian BBLR Di Kabupaten Belitung Timur Provinsi Kepulauan Bangka Belitung Tahun 20102011. Depok: Universitas Indonesia.

Nugroho, C.L. (2012). Perbedaan Luaran Janin Pada Persalinan Preterm Usia Kehamilan 34-36 Minggu Dengan Dan Tanpa Ketuban Pecah Dini Tahun 2012. Semarang: Universitas Diponegoro.
Pantiawati, I. (2010). Bayi dengan BBLR (Berat Badan Lahir Rendah). Yogyakarta: Nuha Medika.

Prawirohardjo, S. (2007). Ilmu Kebidanan. Jakarta: Yayasan Bina Pustaka Sarwono Prawirohardjo.

Pofil Kesehatan Provinsi Riau. (2012). Data Dinas Kesehatan Provinsi Riau. Pekanbaru.

RSUD Arifin Achmad Provinsi Riau, (2013). Profil RSUD Arifin Achmad Provinsi Riau. Pekanbaru.

Sistiarani, C. (2008). Faktor Maternal Dan Kualitas Pelayanan Antenatal Yang Berisiko Terhadap Kejadian Berat Badan Lahir Rendah (BBLR). Semarang: Universitas Diponegoro.

Suparyanto. (2012). Berat Bayi Lahir. Jakarta. (http://www.rshappyland.com/index.php/artike lkesehatan/483-faktor-faktor-yangmempengaruhi-berat-bayi-lahir). Diakses pada tanggal 6 januari 2014.

Surasmi, A. dkk. (2003). Perawatan Bayi Resiko Tinggi. Jakarta: EGC.

Survei Demografi Kesehatan Indonesia (SDKI). (2012). Laporan Pendahuluan Survei Demografi Kesehatan Indonesia 2012. Jakarta: Badan Pusat Statistik, Badan Kependudukan dan Keluarga Berencana Nasional, Kementerian Kesehatan.

Sutan, R, dkk. (2014). Determinant of Low Birth Weight Infant : A Matched Case Control Study. Open journal of Preventive Medicine, 2014, 4,91-99. Scientific Research. Kuala Lumpur, Malaysia. 